\title{
Simulating the structure of gypsum composites using pulverized basalt waste
}

\author{
Aleksandr Buryanov $^{1}$, Victoria Petropavlovskaya ${ }^{2, *}$, Tatiana Novichenkova $^{3}$, Kirill \\ Petropavlovskii ${ }^{4}$ \\ ${ }^{1}$ Moscow state university of civil engineering, Yaroslavskoye shosse, 26, Moscow, Russia, 129337 \\ ${ }^{2}$ Associate Professor, Building products and constructions Department, TvSTU, 22 Af. Nikitin, Tver, \\ 170026, Russia \\ ${ }^{3}$ Associate Professor, Building products and constructions Department, TvSTU, 22 Af. Nikitin, Tver, \\ 170026, Russia \\ ${ }^{4}$ Graduate student, Higher mathematics Department, TvSTU, 22 Af. Nikitin, Tver, 170026, Russia
}

\begin{abstract}
This paper examines the possibility of simulating the structure of gypsum composite modified with basalt dust waste to make materials and products based on it. Structural simulating of the topological space in gypsum modified composite by optimizing its grain-size composition highly improves its physical and mechanical properties. Strength and density tests have confirmed the results of the simulation. The properties of modified gypsum materials are improved by obtaining of denser particle packing in the presence of hemihydrate of finely dispersed basalt and plasticizer particles in the system, and by engaging basalt waste in the structuring process of modified gypsum stone.
\end{abstract}

\section{Introduction}

The issue of creating a health-saving environment is directly related to the construction material manufacturing, because microclimate created indoors will be determined by chemical composition, properties and quality of the materials to be used for construction [1, $2,3,4]$. Polymer compositions are frequently used as an effort to cut the costs of construction projects $[5,6]$. However, many materials are a health risk, some even trigger chronic disease. For example, formaldehyde found in the resin that is used to make many finishing materials (such as chipboard, fiberboard or putty) can provoking allergic reactions, even diseases of the eyes and respiratory organs.

Environmentally friendly traditional mineral materials and products based on gypsum, clay, lime and cement compounds, cements and ceramics can serve as great substitutes for polymer finishing materials $[7,8,9]$.

Gypsum glue possesses important advantages compared to the above, because it enables implementing most daring and diverse art design solutions, while creating most favorable indoor microclimate. This makes it more viable in the construction industry.

\footnotetext{
* Corresponding author: victoriapetrop@gmail.com
} 
Production of gypsum glue is power-efficient, that is it does not require high firing temperatures; therefore, gypsum panels are safe not only as finished product but also during production [10].

Technology-wise, gypsum panel manufacturing can recycle waste from other sectors $[11,12,13,14,15]$. For instance, basalt dust (waste of production of basalt fiber) can be used as a reinforcing component; currently, it is not recycled in real production $[16,17,18]$.

Use of basalt dust as modifier in gypsum products helps to improve the structure and properties of gypsum stone $[19,20,21]$. Therefore, tests in this domain are needed to determine optimized composition of raw mix in production of facing panels of gypsum with better physical and mechanical characteristics and performance.

In addition to better strength characteristics, use of basalt dust can cut production costs, being waste from basalt fiber manufacturing. Pulverized particles possess the same properties as fibers proper: fire resistance, high thermal stability, and vapor permeability $[22,23,24]$.

\section{Methods}

The raw material used was high-strength gypsum of grade GVVS-16 - $\alpha$-modification gypsum glue made by Samara Gypsum Plant (SGK) based in Samara, Russia. Highstrength gypsum of $\alpha$-modification, brand GVVS-16 made by Samara Gypsum Plant, is described by low water consumption rate of $35-40 \%$, it begins setting after $4-5$ minutes, and complete sets within 20 minutes. Its grain structure is compliant under GOST 125-79 with $0.5 \%$ of $0.2 \mathrm{~mm}$ oversize sieve residue. Water absorption rate is $18 \%$. Compressive strength is $16 \mathrm{MPa}$; tensile strength in bending is 6-7 MPa. $1 \mathrm{~kg}$ contains no more than 10 mg of metal impurities.

For chemical composition of glue GVVS-16 made by the Samara Plant, see Table 1.

Table 1. Chemical composition of Samara high-strength glue, modification $\alpha$

\begin{tabular}{|c|c|c|c|c|c|c|c|c|c|c|}
\hline $\mathrm{Si}_{2}$ & $\mathrm{~A}_{2} 0_{3}$ & $\mathrm{Ti0}_{2}$ & $\mathrm{Fe}_{2} 0_{3}$ & $\mathrm{Ca} 0$ & $\mathrm{Mg} 0$ & $\mathrm{~S}_{3}$ & $\mathrm{Na}_{2} 0$ & $\mathrm{~K}_{2} 0$ & $\mathrm{P}_{2} 0_{5}$ & $\mathrm{~F}$ \\
\hline 0.8 & traces & traces & - & 37.52 & 0.10 & 53.78 & 0.05 & 0.007 & - & - \\
\hline
\end{tabular}

Figure 1 presents a registered diffractometric scanned image of Samara high-strength gypsum, modification $\alpha$.

Key performance characteristics of Samara high-strength gypsum, modification $\alpha$, are presented in Table 2.

Figure 2 presents integral and differential distribution of particles by size in the structure of high-strength gypsum GVVS-16.

The modifier additive was basalt dust that is waste from basalt fiber production. Methods of differential thermal analysis, X-ray diffraction analysis and chemical analysis were used to determine the aggregative and chemical composition of powder waste (Table 3).

Figure 3 illustrates integral and differential particle distribution by sizes in basalt powder.

According to the grain-size analysis, average particle size of basalt dust was $\mathrm{d}_{50}=24.866$ mcm, largest particle size was $d_{99}=111.743 \mathrm{mcm}$, with $9.66 \%$ by mass of particles smaller than $2 \mathrm{mcm}$.

The plasticizer added was Melflux 1461f hyper-plasticizing agent, made by BASF Construction Polymers (Trostberg, Germany).

Studies of the properties of the gypsum modified composite were researched on standard sample bars, sized 40x40x160 mm, tested to meet the provisions of GOST 23789. 
Particles distribution in dust samples was measured with the laser diffraction method under ISO 13320-1:2009 "Size Particle Analysis. Methods of Laser Diffraction", by Analysette 22 laser particle size analyzer. Diffractometric images of gypsum glue and the modified composite on its basis were registered using diffractometer ARL X'tra (Switzerland).

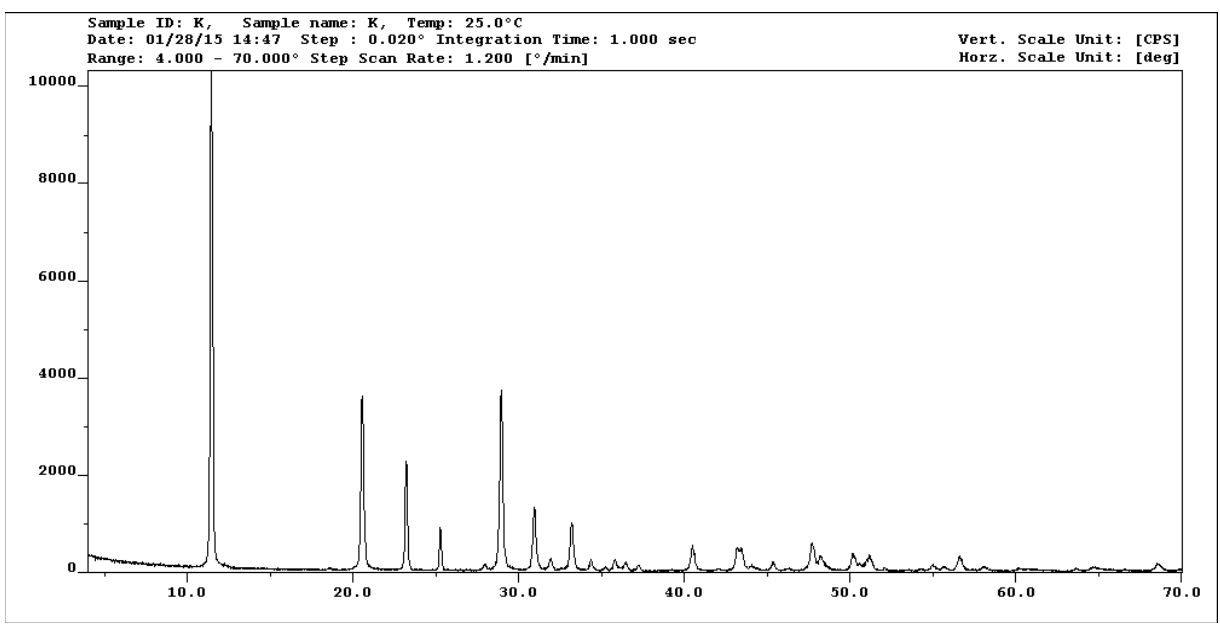

Fig.1.Registered diffractometric scanned image of GVVS-16

Table 2. Key performance characteristics of high-strength gypsum, modification $\alpha$

\begin{tabular}{|c|c|c|c|}
\hline Brand of glue & $\begin{array}{c}\text { Specific area, } \\
\mathrm{m}^{2} / \mathrm{kg} ;\end{array}$ & Expansion by volume, \%; & $\begin{array}{c}\text { Insoluble impurities } \\
\text { in HC1, \%. }\end{array}$ \\
\hline$\Gamma-16$ & 6.893 & 0.13 & 0.17 \\
\hline
\end{tabular}

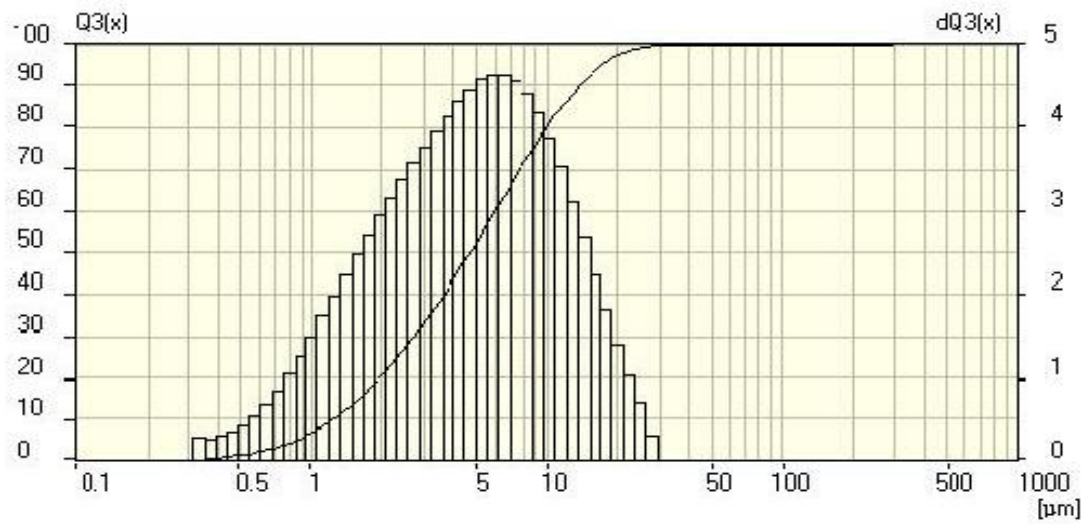

Fig. 2. Integral and differential distribution of particlesin GVVS-16

Table 3. Chemical composition of waste basalt

\begin{tabular}{|c|c|c|c|c|c|c|c|c|c|}
\hline $\mathrm{CO}_{2}$ & $\mathrm{Na}_{2} \mathrm{O}$ & $\mathrm{MgO}$ & $\mathrm{Al}_{2} \mathrm{O}_{3}$ & $\mathrm{SiO}_{2}$ & $\mathrm{SO}_{3}$ & $\mathrm{~K}_{2} \mathrm{O}$ & $\mathrm{CaO}$ & $\mathrm{TiO}_{2}$ & $\mathrm{Fe}_{2} \mathrm{O}_{3}$ \\
\hline 1.45 & 1.58 & 9.06 & 12.14 & 52.67 & 0.65 & 0.57 & 13.92 & 1.10 & 6.87 \\
\hline
\end{tabular}




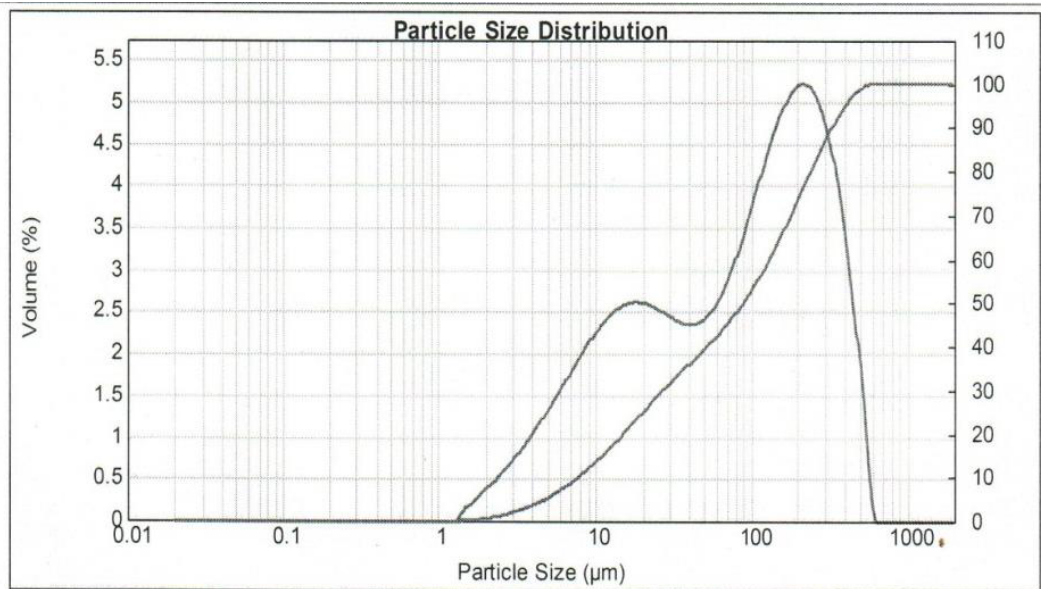

Fig.3. Results of grain size analysis of basalt powder

\section{Results and Discussion}

This paper examines the possibility of simulating the structure of gypsum composite modified with basalt dust waste to make materials and products based on it. The topological structure of the composite was selected with TvSTU software solution [25] by ensuring possibly tight packing of particles of each component. The respective grain size composition of each of the above was used as basis to find the optimal grain composition (Figure 4). Strength and density tests have confirmed the results of the simulation.

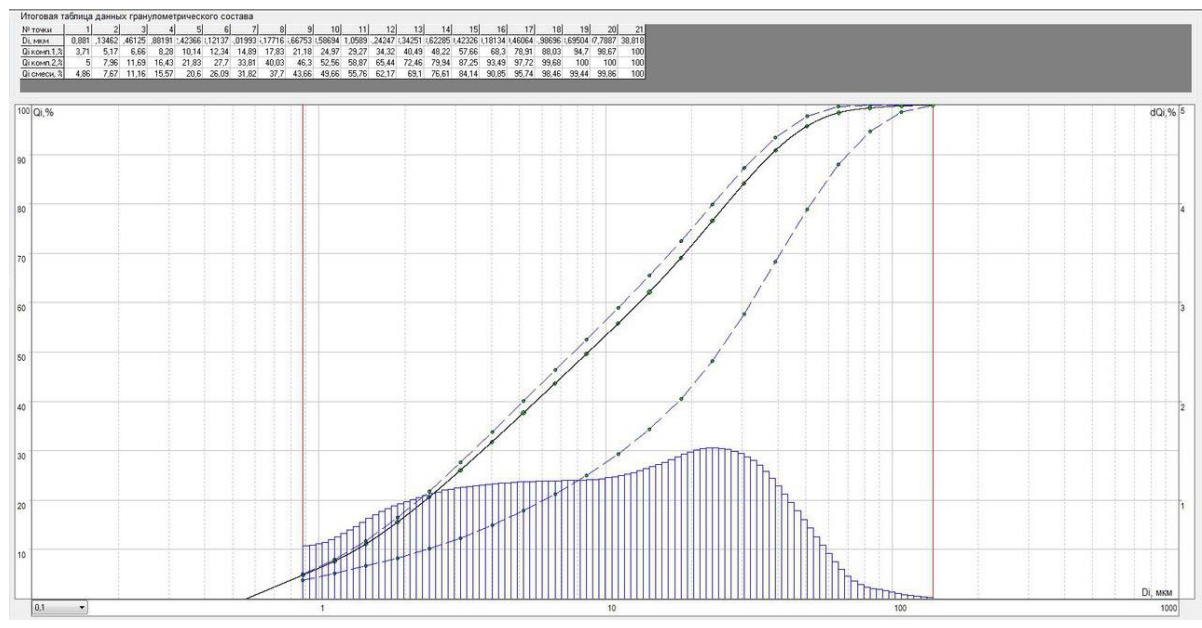

Fig. 4. Results of grain-size structure simulation of gypsum composite by TvSTU software solution

Highest strength of gypsum composite was $7.96 \mathrm{MPa}$, achieved by adding the modifier in $10 \%$ proportion. Average density of composite was $1.687 \mathrm{~kg} / \mathrm{m}^{3}$. The results have experimentally confirmed the data from mathematical calculation. Therefore, optimal content of added modifier based on basalt powder waste was $10 \%$ for tested of gypsum composite.

The next stage conducted a two-factor experiment to research the properties of gypsum composite modified with added basalt powder and Melflux hyper-plasticizer. The adopted 
variable parameters were: water-to-solid ratio ranging between 0.33 and 0.37 , and percentage of plasticizer ranging between 0 and $0.2 \%$. The results are represented in Figures 5, 6, and 7 .

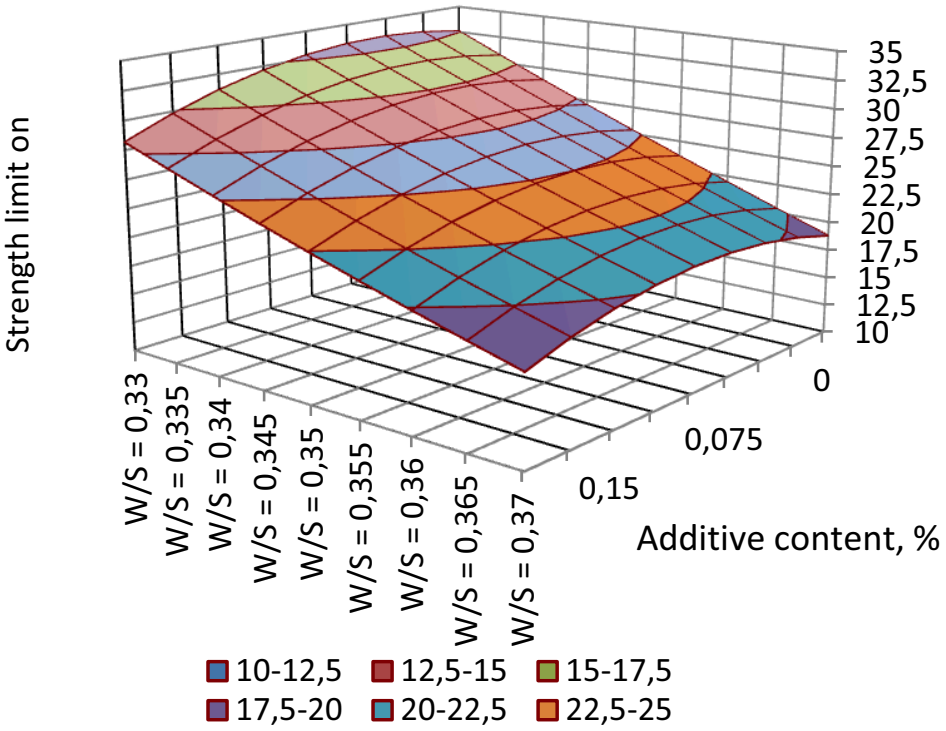

Fig. 5. Dependency of gypsum composite strength on content of Melflux 1461f hyper-plasticizer

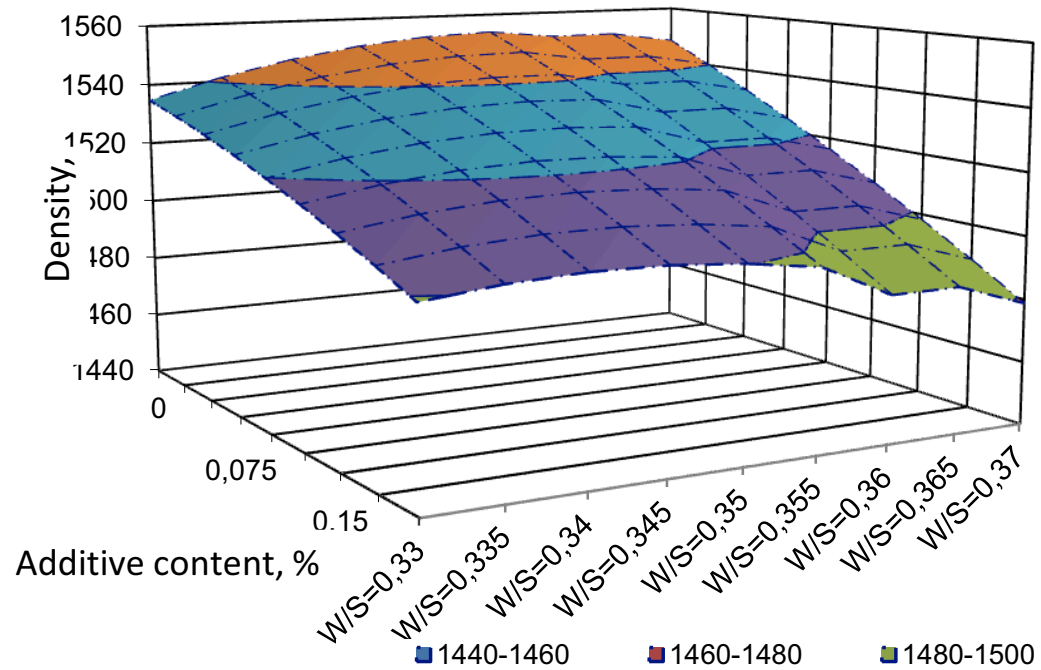

Fig. 6. Dependency of gypsum composite density on content of Melflux 1461f hyper-plasticizer

It has been found that strength of samples aged 7 days for all values of the water-tosolid ratio tends to rise with additive content rate of 0 to 0.075 , as illustrated in Fig. 5 . Further increase of additive content rate works to decrease strength properties.

Highest strength of $33.3 \mathrm{MPa}$ is achieved at the water-to-solid ratio of 0.33 ; the low of 17.5 $\mathrm{MPa}$ occurs at the water-to-solid ratio of 0.37 . 
Increase of plasticizer content slightly decreases density of samples, while porosity rises; this is also due to excessive plasticizing effect (Fig. 2 and 3). Added plasticizer has virtually no effect on the material's density and porosity; this is different from the water-tosolid ratio - this effect can be explained by pores emerging when surplus water evaporates and changing the density of the samples. The lowest density was registered at the water-tosolid ratio of 0.37 ; the highest was registered at 0.33 .

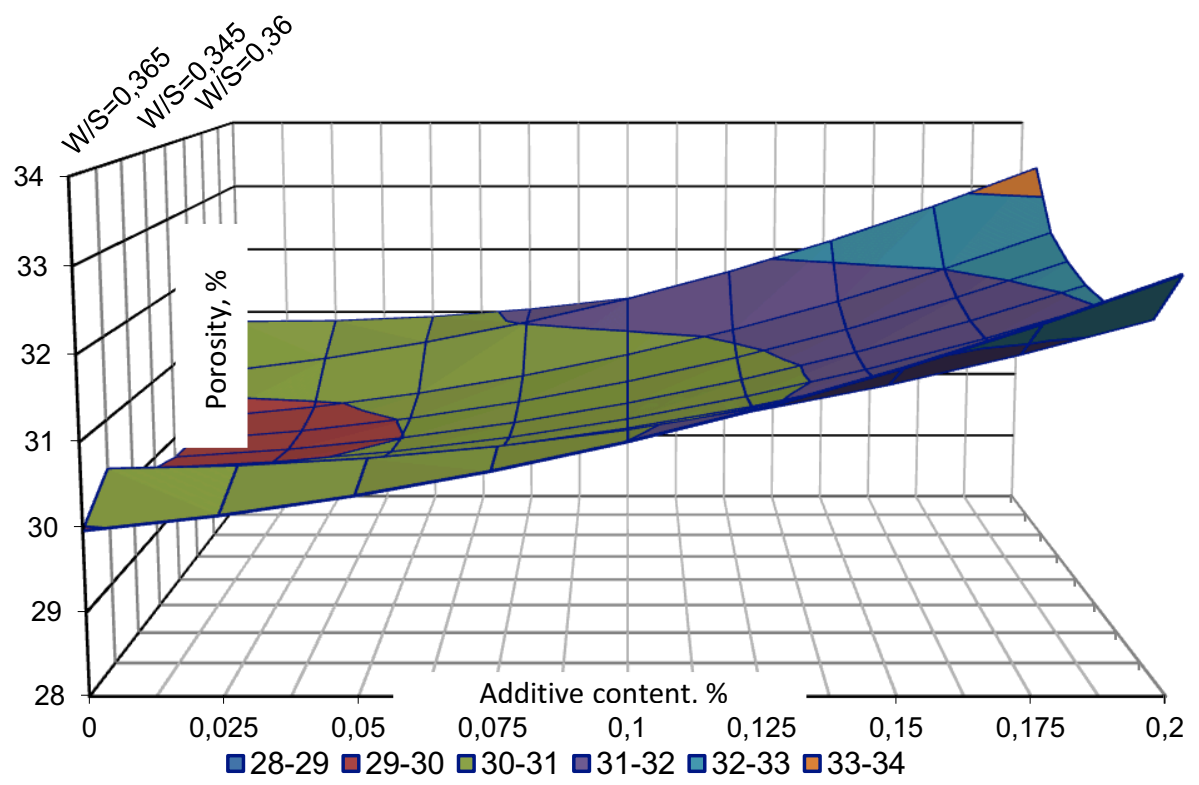

Fig. 7. Dependency of gypsum composite porosity on content of Melflux 1461f hyper-plasticizer

The properties of modified gypsum materials are improved by obtaining of denser particle packing in the presence of hemihydrate of finely dispersed basalt and plasticizer particles in the system, and by engaging basalt waste in the structuring process of modified gypsum stone.

Alkaline components found in basalt raise the environment's alkalinity, thus boosting the process of structuring in the system, because sulfates precipitate best in alkaline environments, as confirmed by the results illustrated in the X-ray photo (Figure 8) and microphotography of the structure of modified composite (Figure 9). Active fusion of calcium sulfate dehydrate particles is observed. The registered diffractometric image of gypsum composite with added basalt fiber demonstrates a rise of background activity under $\mathrm{d}=2.7-3.1 \AA$, indicating the presence of an amorphous component.

\section{Conclusions}

Therefore, seeing the outcome of the above experiments, we can conclude that using basalt dust as additive is a positive effect on the structure of gypsum modified stone. Structural simulating of the topological space in gypsum modified composite by optimizing its grainsize composition highly improves its physical and mechanical properties. The morphology of the crystals depends on the environment's alkalinity. Use of Melflux hyper-plasticizer with modified gypsum composites has borne no significant effect in the researched material. 


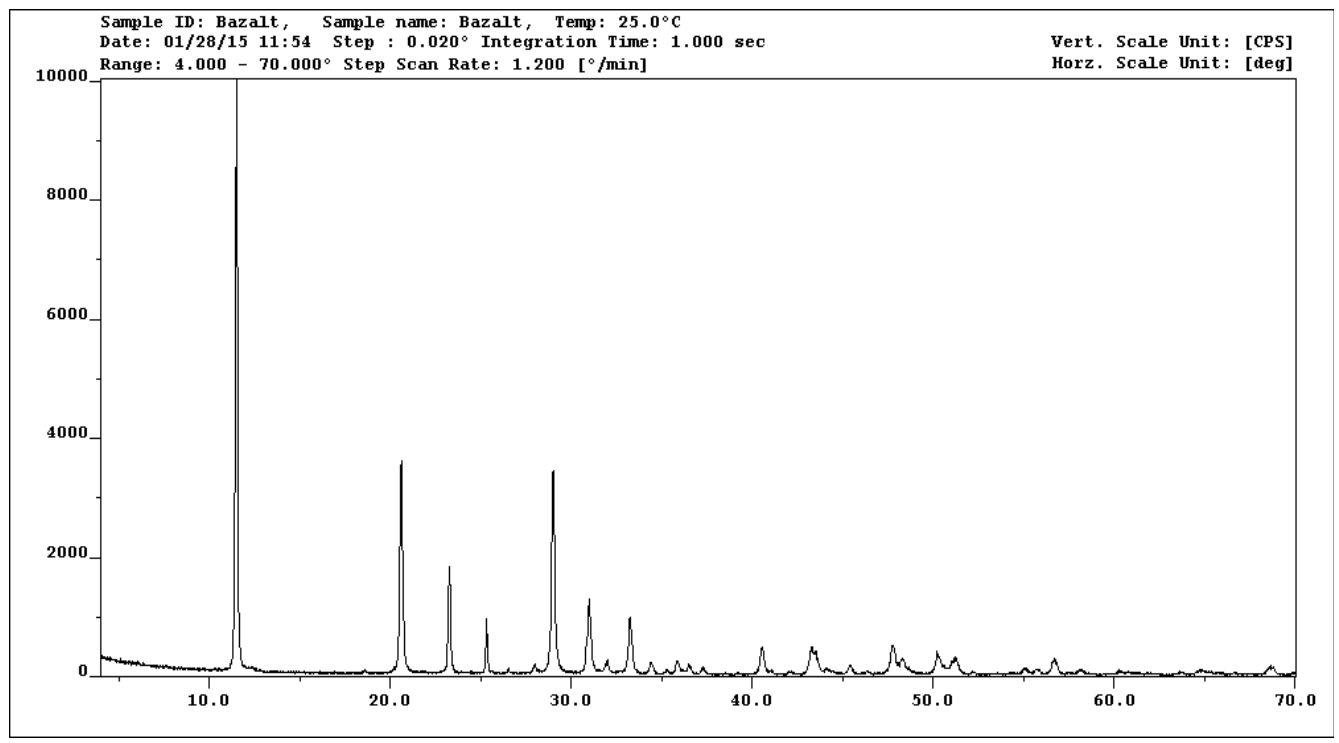

Fig. 8. Registered diffractometric image of gypsum composite with industrial basalt fiber

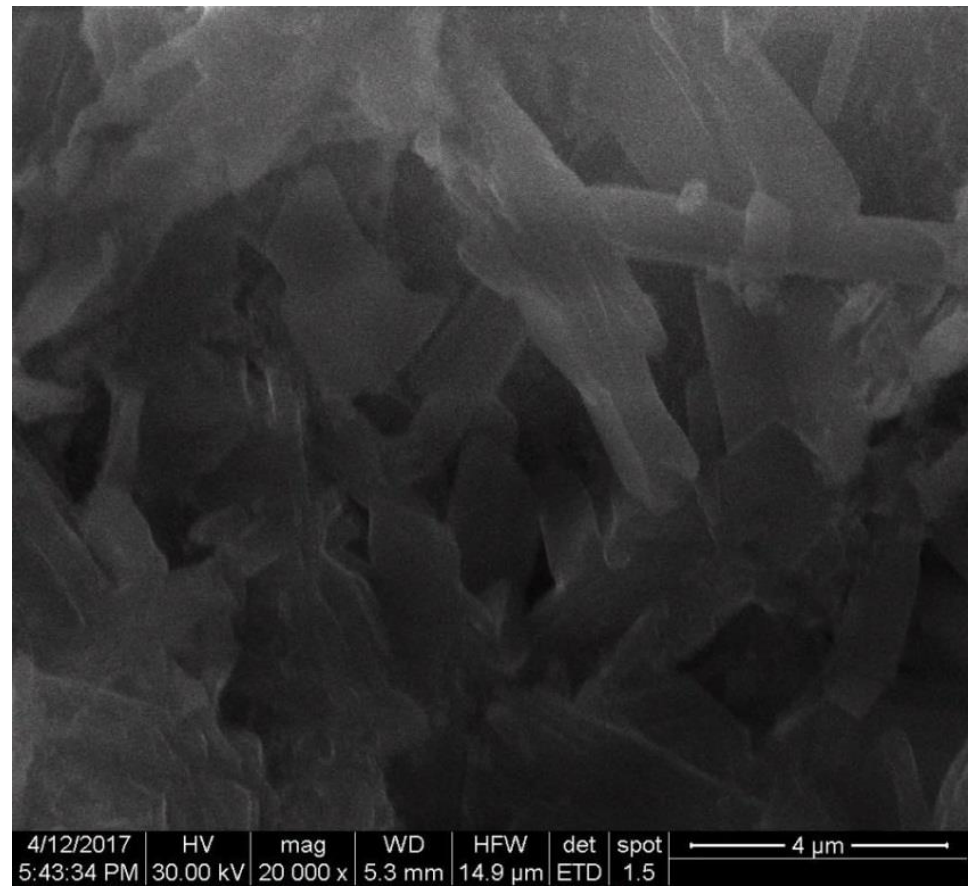

Fig.9. Microphotography of the structure of gypsum composite with industrial basalt fiber 


\section{Acknowledgement}

These authors are profoundly grateful to Professor M.S. Garkavi for his assistance with the research.

\section{References}

1. A. V. Ferronskaya, ets. Gypsum materials and products. ASV (2004).

2. V.B. Petropavlovskaya, T. B. Novichenkova, A.F. Bur'yanov, Yu. Yu. Poleonova, Procedia Engineering 57, pp. 906 -913 (2013)

3. V. V. Belov, A. F. Bur'yanov, G. I. Yakovlev, V.B. Petropavlovskaya, T. B. Novichenkova, etc. M.; De Nova (2012)

4. V.B. Petropavlovskaya, A. F. Bur'yanov, T. B. Novichenkova. Stroitel'nye Materialy, 7, pp. 8-9 (2006)

5. Yu.V. Gontar. Sukhie stroitelnye smesi, 1 (2012)

6. S.P. Sivkov, E.N. Potapova, ets. Sukhie stroitelnye smesi, 3 (2014)

7. N.N. Morozova, N.V. Maysuradze, T.F. Galiev, L.I. Potapova. Vestnik Kazanskogo tekhnologicheskogo universiteta. T. 19. 2 (2016)

8. N.A. Galtseva Innovations and modeling in building materials science. Collection of scientific papers. Under a general edition of V.B. Petropavlovskoy. Tver (2016)

9. V.B. Petropavlovskaya, T. B. Novichenkova, A. F. Bur'yanov, K.S. Petropavlovskiy, H.-B. Fisher. Stroitel'nye Materialy, 7 (2014)

10. R.V. Chizhov, N.I. Kozhukhova, ets. Stroitel'nye Materialy. 3 (2015)

11. L. V. Zavadskaya, G.I. Berdov, ets. Izvestiya vysshikh uchebnykh zavedeniy. Stroitelstvo. 10 (658). (2013)

12. L. V. Zavadskaya, G.I. Berdov, Ya. S. Agalakova, etc. Izvestiya vysshikh uchebnykh zavedeniy. Stroitelstvo. 8 (2013)

13. D. O. Bondarenko, V. V. Strokova, A. M. Rykunov, V. V. Nelyubova. Modern construction materials, technologies and designs: materials of the International scientific and practical conference devoted to FGBOU VPO'S 95 anniversary of "GGNTU of the academician M. D. Millionshchikov" (2015)

14. G.I. Berdov, E.V. Parikova, V.F. Khritankov. Izvestiya vysshikh uchebnykh zavedeniy. Stroitelstvo, 8 (2006)

15. R. R. Ryazapov, R. H. Mukhametrakhimov, ets. Izvestiya KGASU. 3 (2011)

16. H. A. Khezhev, Yu. V. Pukharenko. Vestnik grazhdanskikh inzhenerov. 2 (2013)

17. M. S. Osnos, S. P. Osnos. Composite World. 5(26). (2009)

18. H. A. Hezhev, Yu. V. Pukharenko. Vestnik grazhdanskikh inzhenerov. 2 (2013)

19. D. Mognonov, [et al.] Stroitel'nye Materialy. 10 (2012)

20. L.V. Zavadskaya, L.V. Ilina, G.I. Berdov. Izvestiya vuzov. Stroitelstvo. 7 (2011)

21. M.S Garkavi. Magnitogorsk: MGTU (2005)

22. M. S. Garkavi, third ed. Suhie stroitel'nye smesi. 2, pp. 38 (2013)

23. V. G. Babayev, V. V. Strokova, V. V. Nelyubova. Vestnik Belgorodskogo gosudarstvennogo universiteta imeni V. G. Shukhova: BGTU. 4 (2012)

24. V. Petropavlovskaya, A. Buryanov, T. Novichenkova. Advanced Materials Research, T.467, pp. 91-96 (2014)

25. V.V. Belov, I.V. Obraztsov. Stroitel'nye materialy, oborudovanie, tekhnologii XXI veka. 7 (2012) 